\title{
Sul progetto grafico per l'informazione. Pittogrammi per la comunicazione
}

Gabriella Curti

Abstract

I pittogrammi devono catturare l'attenzione delle persone disorientate per poterle correttamente orientare. Essi devono essere leggibili e comprensibili poiché identificano gli spazi, comunicano informazioni sui servizi da utilizzare, servono a guidare i visitatori stranieri nei territori sconosciuti e a dirigerli nei luoghi di transito per gli spostamenti mediante vari mezzi di trasporto. Interessanti sperimentazioni compiute dai graphic designers inoltre riguardano le manifestazioni sportive olimpioniche. È in corso una ricerca per elaborare una tassonomia degli esempi progettati e individuare delle linee guida alla progettazione.

comunicazione visiva, simbolo, pittogramma, ghrapic design.

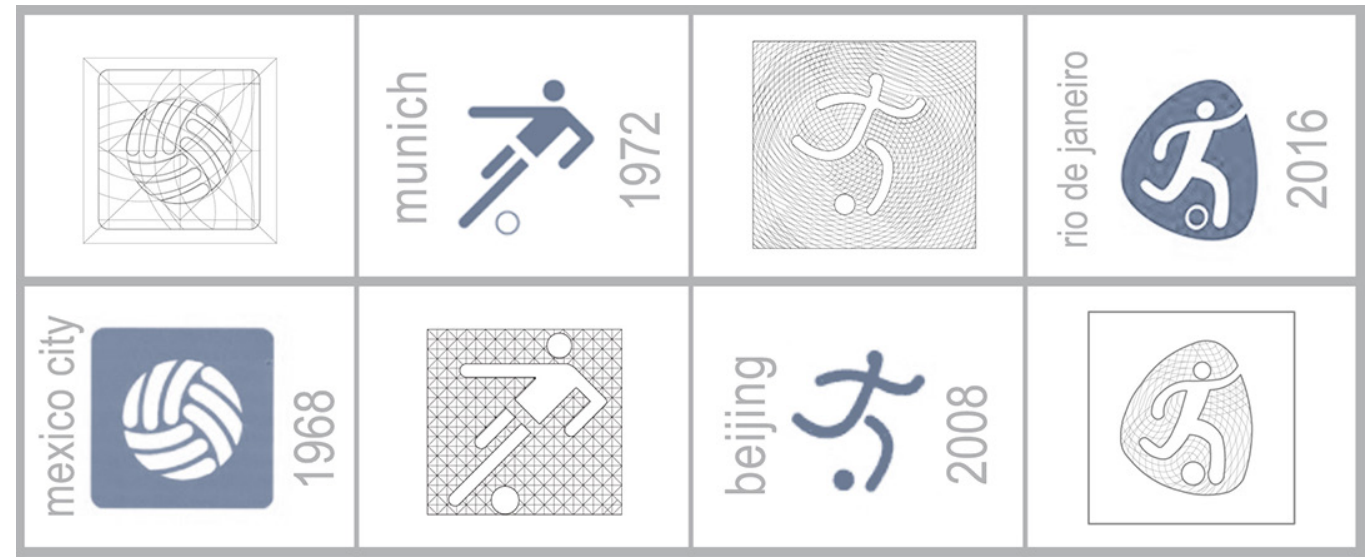




\section{Le ragioni di una ricerca}

Espressione di semplicità nella forma e nella geometria, di suprema sintesi nei dettagli degli elementi raffigurati e nelle combinazioni dei colori, i pittogrammi sono al contempo dotati di forte qualità comunicativa. Essi sono ormai universalmente accreditati e per descriverli si fa riferimento, in primo luogo, alla creazione del sistema Isotype [I].

Realizzati inizialmente per le Grandi Esposizioni che dovevano ospitare una moltitudine di persone proveniente da vari paesi del mondo, i pittogrammi erano dislocati non soltanto negli edifici pubblici ma soprattutto negli aeroporti, nelle stazioni ferroviarie e marittime e negli ambienti urbani. Pertanto, leggibili e comprensibili pittogrammi potevano aiutare i visitatori negli spostamenti da un luogo all'altro e consentire loro di individuare gli spazi verso i quali dirigersi e le attività da compiere pur non conoscendo la lingua del luogo in cui si trovavano.

Le numerose serie progettate mostrano da una parte la ricerca della sintesi formale coniugata all'espressività, non senza il rispetto di regole anche nelle esemplificazioni più creative, e dall'altra il tentativo dei graphic designers di ricorrere a semplici trasgressioni per le nuove elaborazioni.

Data la vastità delle esemplificazioni realizzate a partire dalla seconda metà del XX secolo, risulta complesso il tentativo di elaborare una sorta di tassonomia degli esempi elaborati, tuttavia se da una parte con il presente contributo si è inteso presentarne una piccola rassegna - quasi un piacevole gioco di combinazioni - dall'altra si è pensato di invitare a riflettere sulle affinità e differenze, considerando geometrie, forme e colori per individuare, infine, delle linee guida alle modalità di progettazione.

Fig. I. Alcuni dei pittogrammi in uso per le informazioni utili agli utenti, compreso segnali per azioni consentite per azioni consentite o netate, nel contrasto moelaborico biancolnero Gabriella Curti).

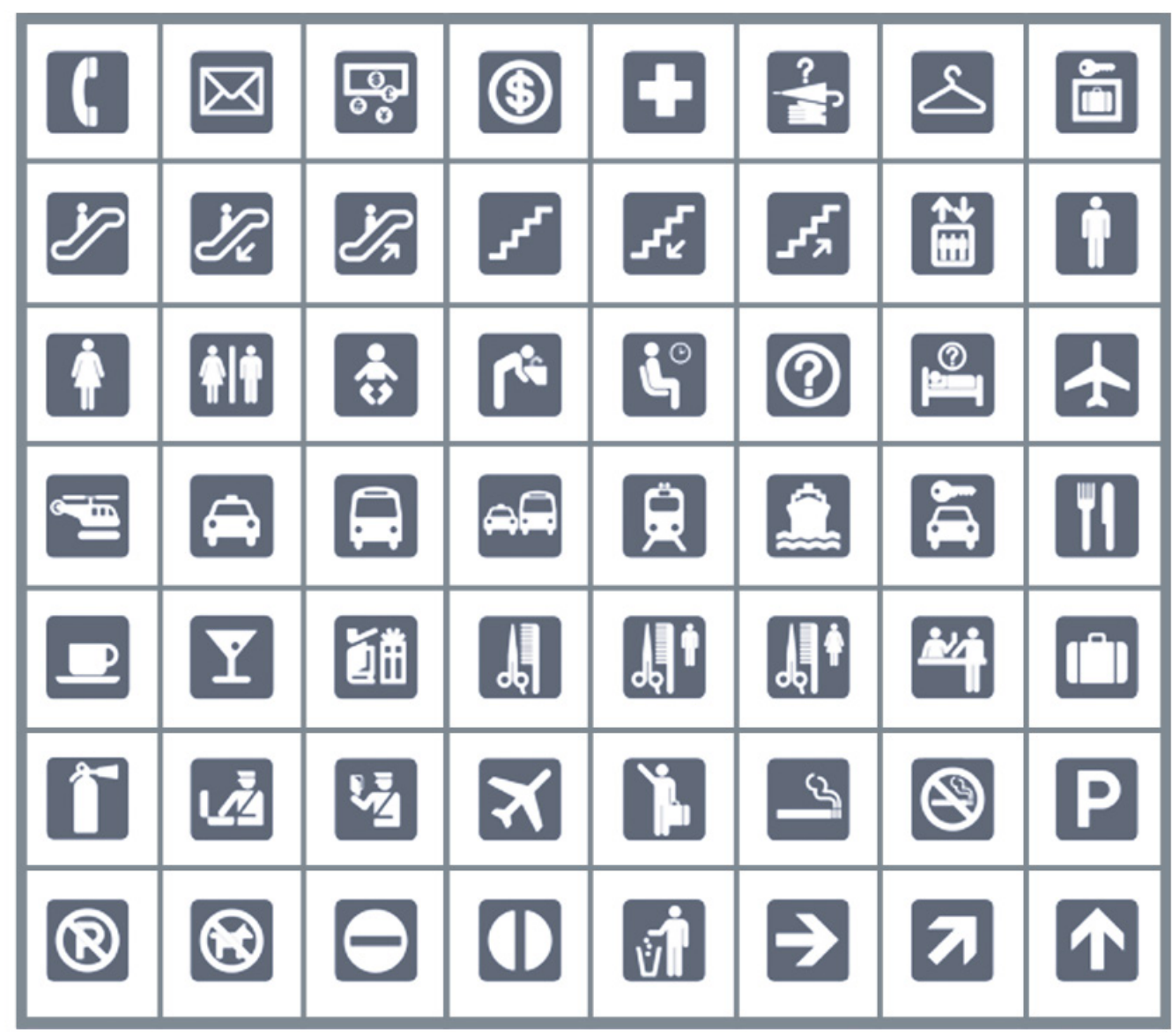




\section{Simbolismo e significato delle espressioni iconiche}

La realizzazione di immagini come simboli risiede nelle tracce lasciate dalle più antiche civiltà. È opportuno ricordare che, prima dell'invenzione della scrittura, i pittogrammi erano frequentemente usati poiché era essenziale, in luogo delle parole, la loro espressione simbolica [2]. Si rammenta che la scrittura cuneiforme - dalla civiltà sumerica a quella assiro-babilonese - utilizzava segni, simboli e pittogrammi. Anche successivamente all'invenzione della scrittura, essi si sono rivelati essenziali per una comunicazione rapida ed efficace, infatti sono stati definiti "una forma di stenografia" [Heller, Anderson 2016, p. I02].

Si potrebbe fare un parallelo con altre forme di espressione, come quella gestuale e ottica. II ricorso alla gestualità sembra che sia sempre più accentuato per la necessità di accompagnare espressioni verbali vernacolari (e quindi ignote agli altri non residenti nello stesso luogo) con gesti che una volta sembravano strani. Allo stesso modo si registra un più eloquente uso delle espressioni facciali, dello sguardo ad esempio, per stabilire un diretto contatto con gli interlocutori.

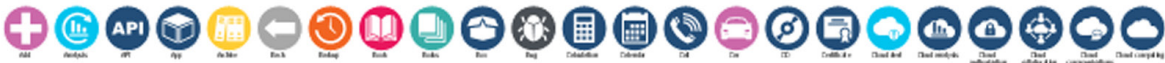

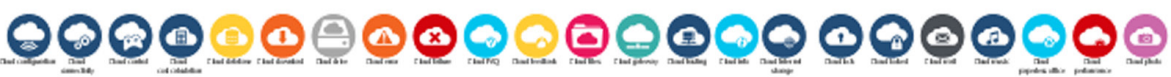

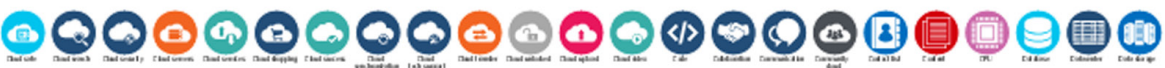

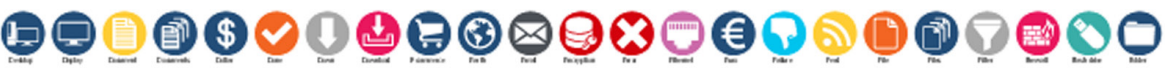

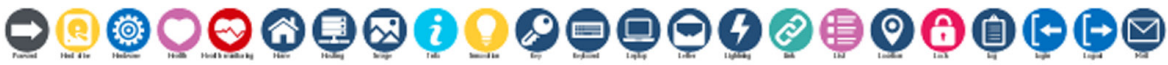

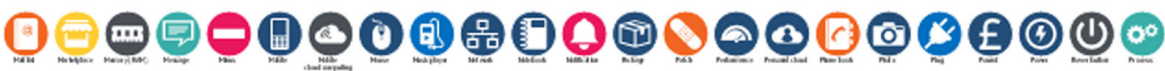

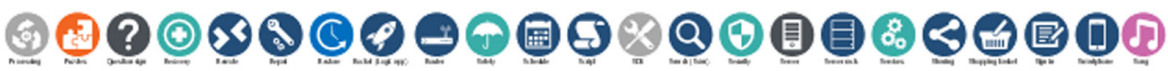

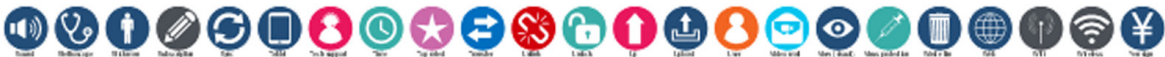

12 Colour Palette
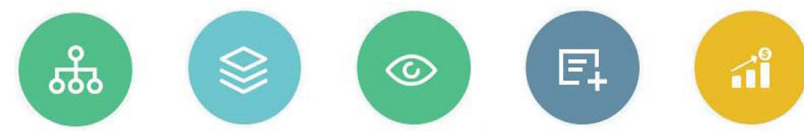

In's
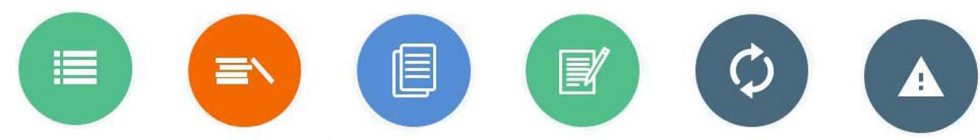

7 Colour Palette
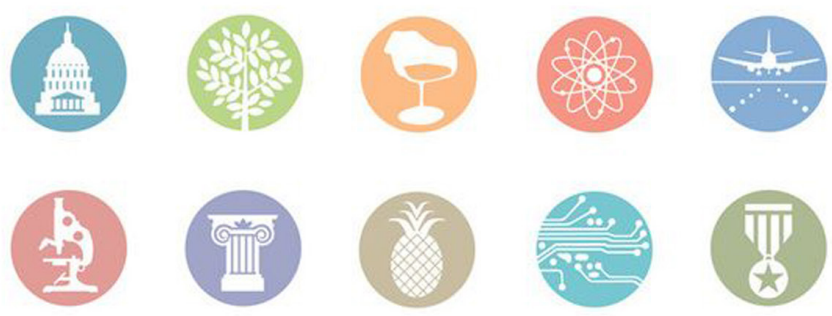

9 Colour Palette 
Alle espressioni non verbali si fa ricorso anche nell'universo digitale mediante i segni di interpunzione (segni paragrafematici comuni in quasi tutte le lingue moderne) che, abbinati tra loro, sembrano individuare le espressioni ricorrenti sul volto. La prime immagini grafiche denominate emoticon (termine derivante dalla combinazione dei termini inglesi emotion e icon) sono state sostituite dalle emoji (termine giapponese che è la combinazione di ' $e$ ' che significa immagine e 'moji' che significa personaggio). I primi sono una combinazione di caratteri speciali che accompagna brevi messaggi di testo per esprimere stati d'animo e i secondi sono dei pittogrammi costituiti da piccole forme circolari, rappresentazioni simboliche del volto umano e delle sue espressioni, il cui sfondo piatto è prevalentemente di colore giallo a cui si abbinano i segni di colore nero (eventualmente anche bianco e rosso). In questo caso è stato utilizzato il primo tra i contrasti individuati nella scala dei contrasti che offrono la massima leggibilità [3]. II simbolismo delle espressioni fisiche è racchiuso nelle immagini codificate che sono tutte della stessa forma e dimensione e dello stesso colore. Ciò favorisce la comprensione dell'utilità della rappresentazione pittografica comprendente un ampio repertorio di simboli che hanno tutti una relazione visibile con il concetto che esprimono, oppure con l'entità a cui si riferiscono sia esso un luogo, uno spazio, un'attività, un oggetto [4].

Nel vasto ambito dei pittogrammi, l'indicazione degli spazi per le attività è compiuta mediante la rappresentazione degli elementi intrinseci all'attività stessa e, per la loro connotazione, le componenti più importanti e determinanti sono due: la forma e il colore. La forma semplice spesso si abbina ai colori base, tuttavia alcune interessanti variazioni nella rappresentazione simbolica e nelle combinazioni di colore documentano una ricerca grafica alquanto promettente (figg. I, 2).
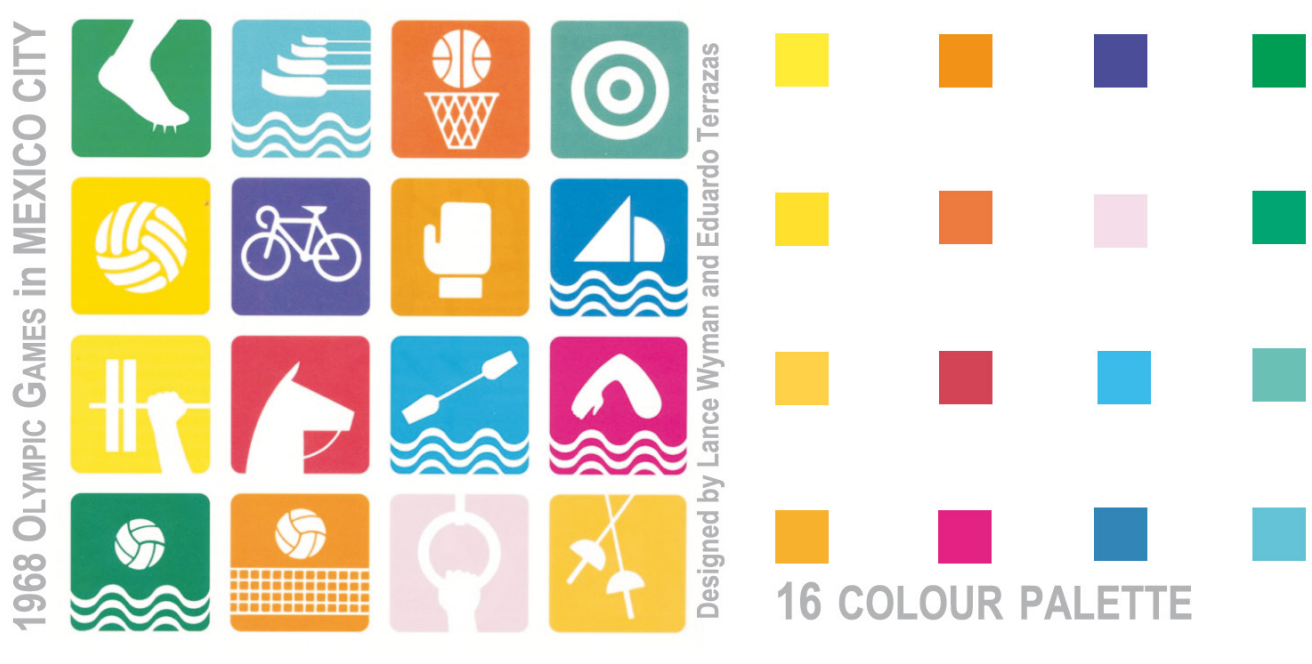

\section{Forme, geometrie e colori dei pittogrammi}

È facile rilevare che due forme geometriche semplici (cerchio e quadrato) siano state maggiormente impiegate per la loro funzionalità e versatilità. La forma circolare è molto usata per segnalare divieti o per fornire informazioni. Esistono numerose varianti sia per l'uso delle linee di contorno di vario spessore e colore, sia per l'uso delle campiture di superficie su cui si staccano i simboli (in bianco o nero) per ottenere efficaci contrasti monocromatici. La forma quadrata per consuetudine è impiegata quasi esclusivamente per informazioni di servizio all'utenza. Questa presenta uno o più elementi simbolici e diverse modalità di traccia- 
mento del contorno e di impiego delle campiture di superficie. Il rettangolo a volte è usato per sperimentazioni particolari sulla portata simbolica dell'elemento in esso raffigurato e il triangolo costituisce un'interessante applicazione per l'informazione di carattere preventivo come nella segnaletica stradale, laddove è usato per le indicazioni di pericolo.

In generale, l'impiego delle forme circolari, quadrate, rettangolari e triangolari segue consolidate regole di trasmissione delle informazioni secondo il già citato sistema Isotype. Inoltre, i pittogrammi possono essere combinati in un ampio numero e disposti sopra cartelloni che vengono sistemati e affissi su altre superfici per renderli immediatamente visibili. Alcuni simboli isolati sono applicati alle superfici orizzontali e verticali degli spazi esterni mentre, negli spazi interni degli edifici pubblici, i simboli sono raffigurati sopra autonome superfici opache o trasparenti, poste in alto o in basso negli spazi di connessione, per segnalare agli utenti i percorsi da seguire e le localizzazioni dei servizi necessari.

Alle geometrie regolari è stato abbinato l'uso dei colori base che, considerati nella loro massima intensità, tendono a esaltarsi a vicenda determinando un effetto energico e vivace. Le combinazioni tra colori primari, giallo-rosso-blu, e il bianco o il nero rendono particolarmente evidente e leggibile ogni elemento. Pertanto, il colore blu indica le azioni

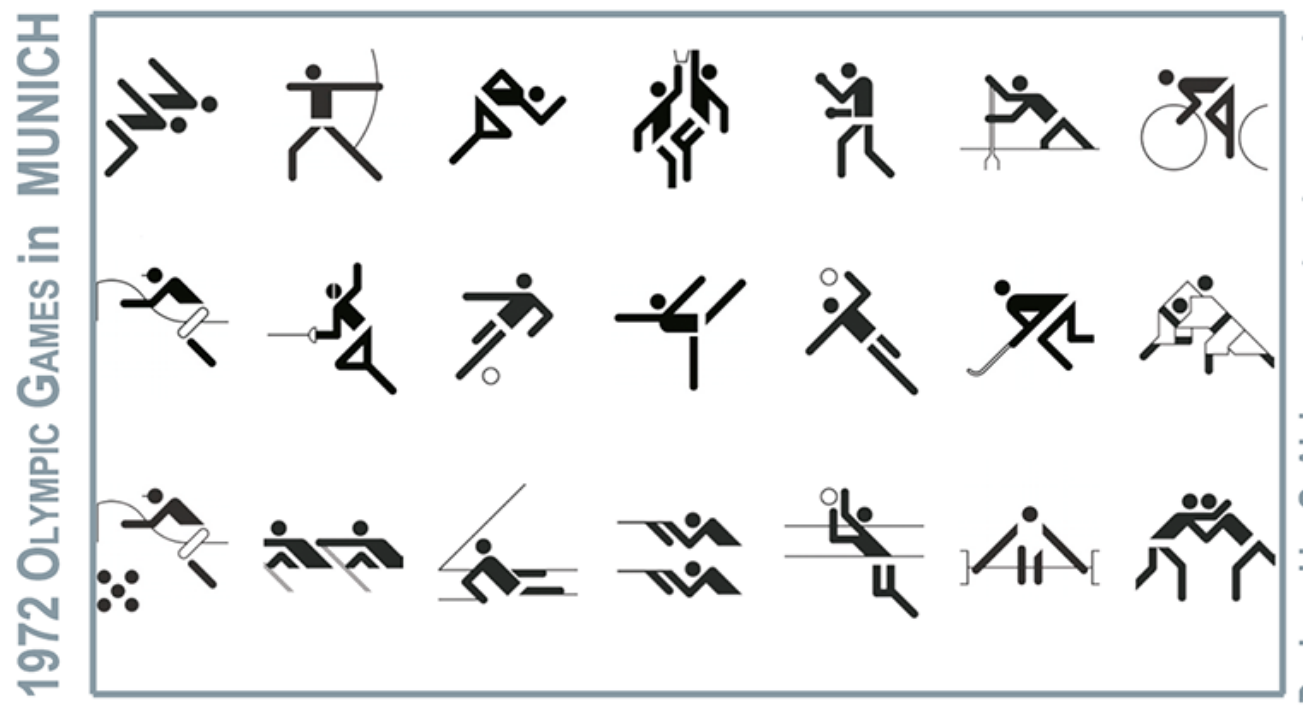


Fig. 5. Pittogrammi per i Giochi di Lillehammer del 1994, progetto di S.E. Rosenbau: la serie per i Giochi Olimpici di Sydney del 2000 progetto del 2000, progetto (elaborazione orafica di (elaborazione grafica consentite e il colore rosso quelle vietate. Ai tre colori base si aggiunge il colore verde per analoghe combinazioni sia con il bianco, sia con il nero. In generale, per le indicazioni di servizio all'utenza sono frequentemente utilizzati supporti verdi, azzurri o blu con simboli in bianco e viceversa.

Se inizialmente per la maggior parte dei pittogrammi prevalse il contrasto monocromatico bianco/nero o bianco/blu, in seguito l'uso del colore è divenuto preponderante, pertanto molte sperimentazioni mostrano l'impiego di un'ampia gamma all'interno di una stessa cromia.
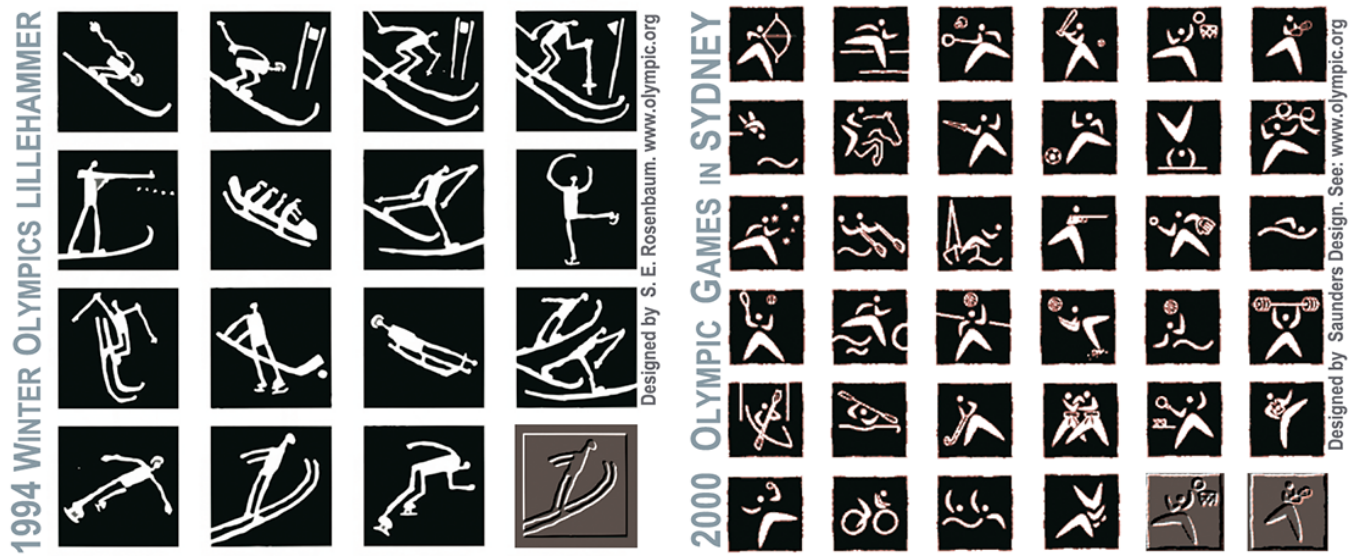

Esempi per le discipline sportive

A partire dal 1960, numerose serie di pittogrammi sono state progettate per i Giochi Olimpici. La serie progettata per le Olimpiadi del Messico del 1968, per riferirsi alle diverse attività sportive, presenta l'uso di parti del corpo o di strumenti mediante la forma in bianco senza contorno sullo sfondo a colori. L'uso di un'ampia tavolozza di colori ha reso i simboli ancora più efficaci (fig. 3).

Successivamente, le sperimentazioni monocromatiche utilizzano il nero su fondo bianco e viceversa. Alcune di queste interessanti realizzazioni presentano differenze sull'uso del tratto. Dal segno preciso [5] a quello fluido, tracciato con il pennello [6], il vasto repertorio dei pittogrammi per le attività sportive mostra la creatività dei progettisti che hanno fatto ricorso all'uso di simboli della storia dei luoghi e finanche alla citazione della più antica rappresentazione rinvenuta in una caverna preistorica [7] (figg. 4-6).

Pur mantenendo perlopiù il contrasto monocromatico, il colore è stato impiegato in varie tonalità inoltre, nella serie progettata nel 2012 per i Giochi Olimpici a Londra, la rappresentazione della silhouette dell'atleta ha sostituito le precedenti schematizzazioni simboliche (fig. 7). La silhouette tracciata con una linea continua di spessore variabile, in riferimento ai caratteri dei testi, che sembra simulare i movimenti dell'atleta, si inserisce nel pittogramma a forma di sasso della serie per i Giochi Olimpici di Rio de Janeiro del 2016 (fig. 8).

Appunti di linee guida per la progettazione

Per rendere i pittogrammi efficaci, dunque, si è fatto ricorso alla semplicità nella forma, nella geometria degli elementi raffigurati e nelle combinazioni dei colori. La creazione di forme estremamente stilizzate è stata facilitata dal processo di riduzione progressiva all'essenziale già compiuto dai teorici e artisti agli inizi del $X X$ secolo. Si ricordano le riflessioni di Wassily Kandinsky sulla sintesi espressiva della forma astratta. Egli scrisse: "Questa molteplicità e complicatezza nell'espressione della forma 'minima' - raggiunta pur tuttavia per mezzo delle 
piccole variazioni della sua grandezza - offrono anche a chi non sia prevenuto un esempio plausibile della forza e della profondità espressiva delle forme astratte" [Kandinskj 1926].

Nel tentativo di individuare le principali linee guida per la progettazione, si segnalano alcuni parametri di riferimento che vanno dalla costruzione di una griglia, per l'impostazione geometrica regolare, all'uso di immagini simboliche bidimensionali e senza l'inserimento di effetti chiaroscurali per realizzare volumi e/o vuoti mediante la tridimensionalità. Le combinazioni di colore sono molteplici: dall'uso di una tavolozza ampia oppure ridotta a poche tonalità all'uso del colore unico per il contrasto monocromatico. L'analisi grafica compiuta su alcuni dei pittogrammi per le attività sportive (in particolare, per il gioco del calcio) rivela il probabile ricorso degli autori a una griglia di riferimento costruita sia per il tracciamento dei segni rettilinei che curvilinei (fig. 9).

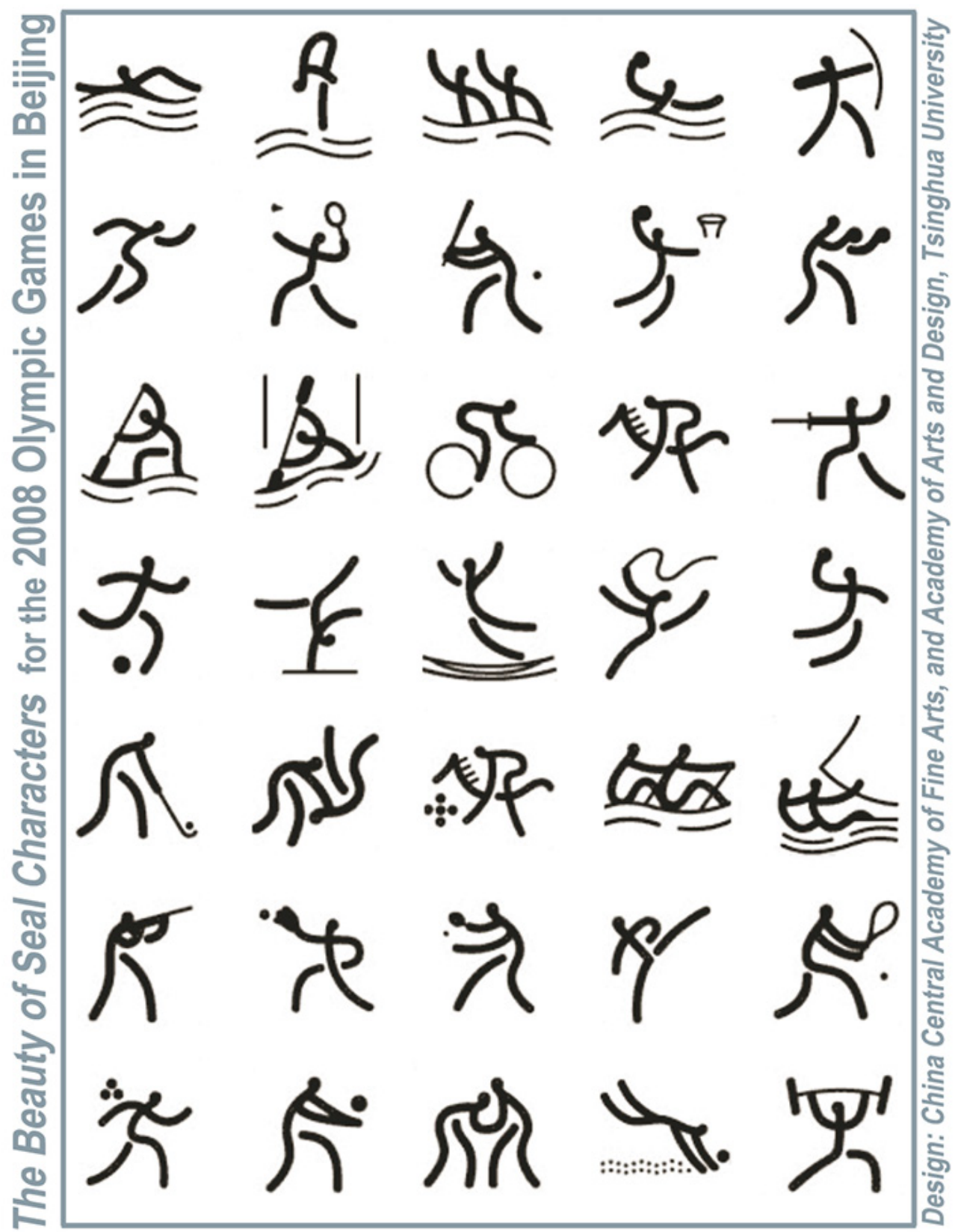


Fig. 7. Pittogrammi per i Giochi Olimpici di Londr del 2012 progettati da Wally Olins e Michael Wolff (fondatori della Wolff Olins nel 1965). In $<$ www.wolffolins.com> (elaborazione grafica d Gabriella Curti).
Fig. 8. Pittogrammi per Glochi Olımpici di Rio de Janeiro del 2016 progettati da Rio 2016 Organising Committe for the Olympic and Paralympic Games. In $<$ www. olympic-museum. de> (elaborazione grafica di Gabriella Curti).
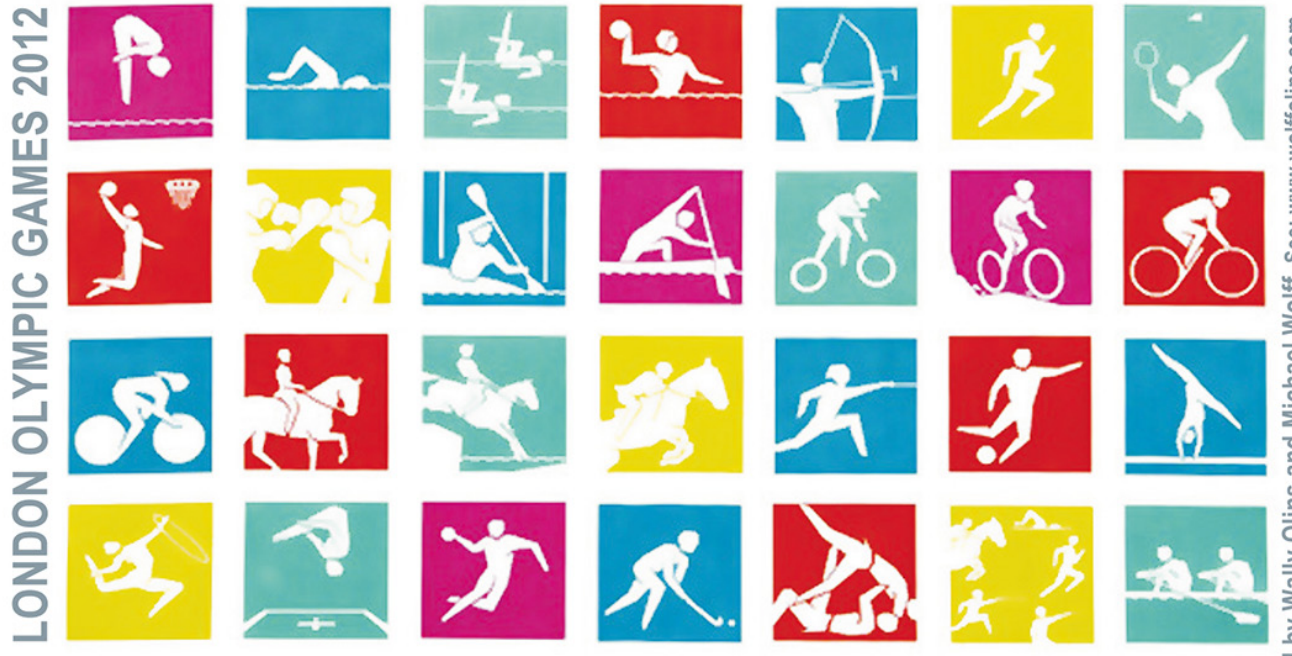

5 COLOUR PALETTE

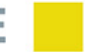

Nonostante alcuni elementi variabili, si vuole mettere in evidenza che, nel confrontare tra loro gli esiti raggiunti dagli autori delle esemplificazioni presentate, è emersa la necessità di riflettere sulla possibilità di mantenere inalterati alcuni standard di riferimento. Poiché l'abbinamento forma-colore è codificato, si sottolinea che ogni deroga potrebbe non essere correttamente interpretata e dare adito a dannosi fraintendimenti. Nei luoghi di massimo transito l'informazione potrebbe essere cruciale. Sovente capita di osservare negli spazi di connessione tra varie aree e tra vari piani, oppure sulle porte d'ingresso ai locali di servizio, la disposizione affiancata dei vari simboli che ci obbliga a riflettere un momento prima di comprendere come muoversi.

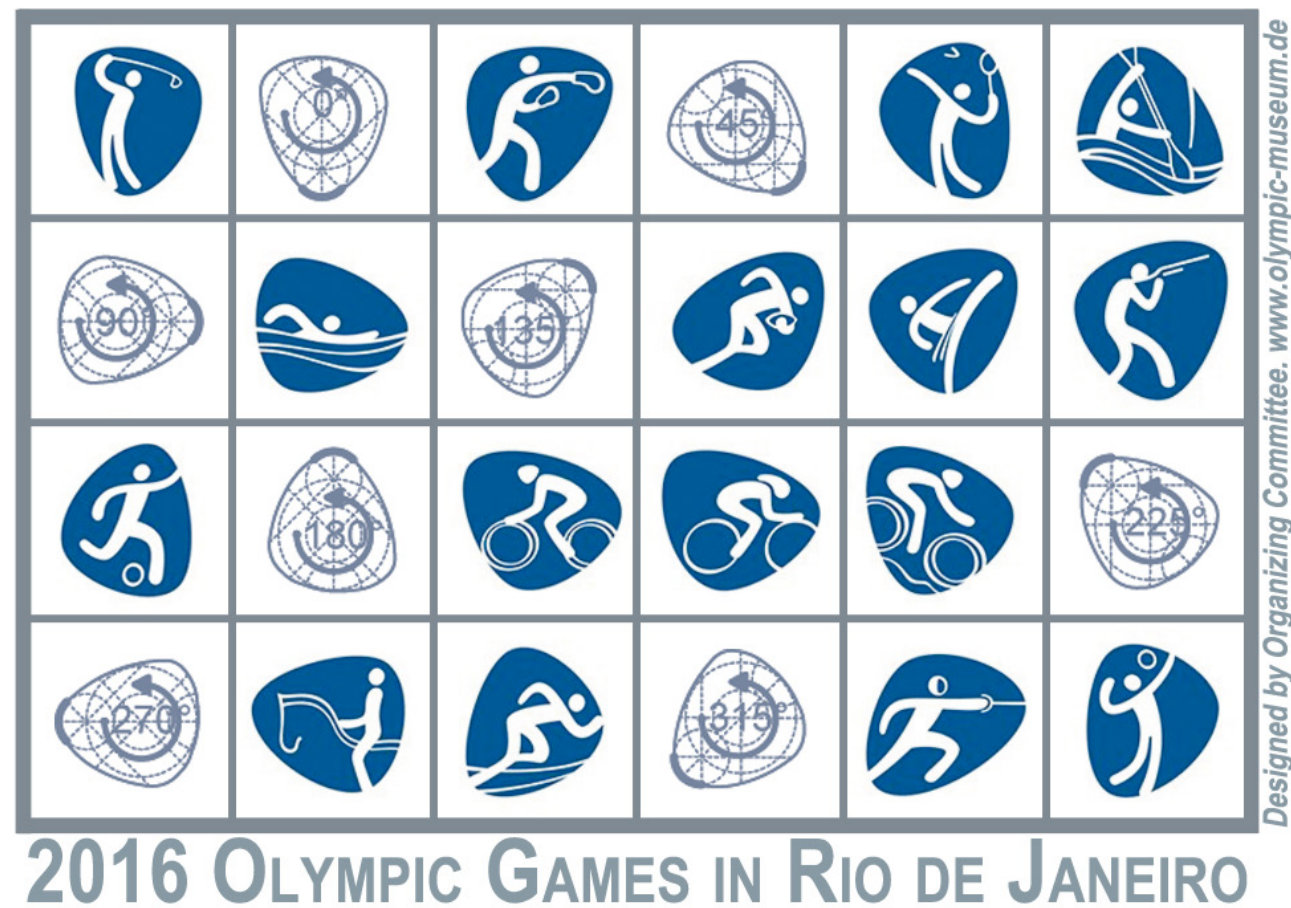


Sembra opportuno chiedersi che cosa accadrebbe se non si trovassero i simboli a cui tutti ormai sono abituati, nel caso in cui questi fossero sostituiti da altri. Esempi interessanti, dal punto di vista stilistico o della creatività che li ha generati, ma incomprensibili per gli utenti meno esperti, potrebbero generare quel caos che si cerca di evitare proprio con l'uso di simboli e segni riconoscibili. La massima fruibilità degli spazi pubblici è anche risultato di una buona informazione per l'utenza, che si misura in base alla quantità di simboli presenti e in relazione alla loro efficiente comunicazione [8].

Secondo il protocollo dell'International Standardization Organisation (ISO) la realizzazione dei simboli deve essere sottoposta alle verifiche relative alla comprensione e alla riconoscibilità. II progettista grafico, quindi, deve prestare attenzione ai parametri e ai vincoli relativi al progetto da realizzare. Molte proposte interessanti in valide alternative sono state espresse, peraltro è probabile che stringenti restrizioni abbiano potuto costituire un forte stimolo allo sviluppo della creatività.

L'immaginazione congiunta all'attenzione e al rispetto per l'utenza sono motivazioni necessarie e sufficienti per giustificare le deroghe e consentirne la loro applicabilità, tuttavia è sempre opportuno chiedersi se sia mantenuto lo standard qualitativo richiesto.

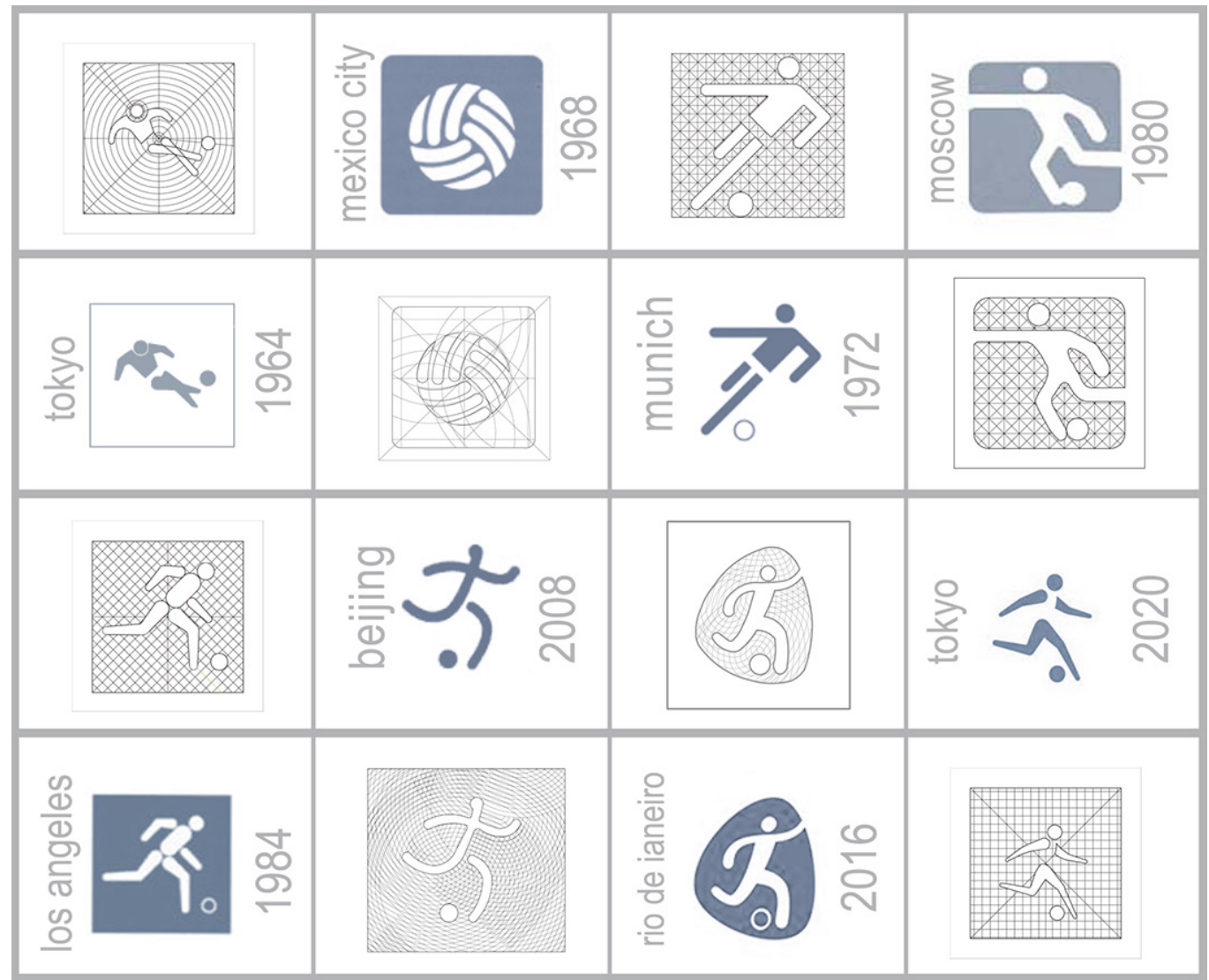

\section{Note}

[I] Isotype (acronimo di International System of Typographic Picture Education) è stato progettato e realizzato tra il 1925 e il 1934. Gli autori, Otto Neurath e Gerd Arntz, intesero comunicare visivamente le informazioni e diedero la spinta alla creazione di un linguaggio visivo che potesse sostituire i testi scritti. L'uso del colore (limitato e ben combinato: sei colori per dieci combinazioni) favoriva la lettura in soli tre livelli (o sguardi)

[2] Leveni 2013, pp. 26-30. L'autore ha scritto: "i pittogrammi sono stati i primi tentativi di rappresentare la realtà [....] con questi segni si indicavano eventi atmosferici [...] esperienze di vita. [...] i segni per comunicare sono stati una vera e propria lingua." 
[3] Sulle combinazioni dei colori si veda Spera 200I, p. 257 nota. L'autore sottolinea che ai primi posti della "scala di valori scientificamente accreditata" si notano le superfici di colore chiaro su cui si staccano i segni di colore scuro, mentre l'abbinamento al contrario delle superfici di colore scuro su cui si staccano i segni di colore chiaro si colloca agli ultimi posti della scala. I colori sono sei, mentre più ampio è il numero delle combinazioni.

[4] I simboli più comuni per la percorribilità e l'uso degli spazi esterni e interni sono: parcheggio-scala-scala mobile-ascensoredeposito-toilette etc. Altri per segnalare i servizi: estintore-valigia-ombrello-busta-ricevitore telefonico-chiave-monete e anche bicchiere-tazza-posate etc.

[5] Nel 1972, Otl Aicher progettò la famosa serie per i Giochi Olimpici di Monaco. In: <www.olympic.org>.

[6] II pennello della tecnica pittorica è stato usato da Josep M. Trias per la serie progettata per i Giochi Olimpici di Barcellona del 1992

[7] Serie per le Olimpiadi di Lillehammer del 1994. L'autrice Sarah E. Rosenbaum prese ispirazione dai dipinti su roccia rinvenuti in Norvegia. In: www.theolympicdesign.com. Essendo stata utilizzata la più antica rappresentazione di un uomo sugli sci, risalente a 4000 anni prima e rinvenuta in una caverna, questi pittogrammi sono stati descritti, pertanto, come i primi simboli progettati per raccontare la storia. M. Osterwalder, Segretario-Generale della International Society of Olympic Historians (ISOH), lo ha sottolineato in una intervista. In: <www.olympic.org. Nei pittogrammi per i Giochi Olimpici di Sydney, le silhouettes hanno la forma del boomerang in omaggio agli aborigeni australiani. In: <www.olympic.org >.

[8] Si segnala il sistema informativo elaborato nel 1980 da Josef Müller-Brockman per la Swiss Federal Railways (SBB), ampliato nel 1992. In: Janser, Spalinger 2019.

\section{Riferimenti bibliografici}

Aymerich Marta (2008). Simboli, pittogrammi \& silhouette. Modena: Logos (Ed. orig. Symbols, pictograms \& silhouettes. Barcelona: Index Book, 2008).

Gallagher Mark, Savard Laura (Blackcoffee) (2006). 1000 simboli e pittogrammi: comunicazione visiva per tutte le lingue. Modena: Logos (Ed. orig. 1000 Icons, Symbols + Pictograms. Beverly, MA: Rockport Publisher, 2006).

Heller Steven, Anderson Gail (2016). Il libro del Graphic Design. Milano:Vallardi (Traduzione a cura di Aster Studio). (Ed. orig. The Graphic Design Idea Book: Inspiration from 50 Masters. London: Laurence King, 20 I6).

Janser Andres, Spalinger Peter (2019). Passenger Information System. Zurich: Integral Lars Müller.

Kandinsky Wassily (1968). Punto, linea, superficie. Milano: Adelphi (Traduzione di Melisenda Calasso). (Ed. orig. Punkt und Linie zu Fläche. Munich: Albert Langen, 1926).

Leveni Paolo (2013). In forma di parola: pittogrammi, ideogrammi, alfabeti, scritture dalla preistoria all'età moderna. Milano: BookTime.

Modley Rudolf, Myers William R. (1976). Handbook of pictorial symbols. 3,250 Examples from International Sources. New York: Dover Publications.

Spera Michele (200I). La progettazione grafica tra creatività e scienza. Roma: Gangemi editore.

\section{Autore}

Gabriella Curti, Università degli Studi Mediterranea di Reggio Calabria, gabriella.curti@unirc.it

Per citare questo capitolo: Curti Gabriella (2020). Sul progetto grafico per l'informazione. Pittogrammi per la comunicazione/Graphic design for universal information. Pictograms and communication. In Arena A., Arena M., Brandolino R.G., Colistra D., Ginex G., Mediati D., Nucifora S., Raffa P. (a cura di). Connettere. Un disegno per annodare e tessere. Atti del $42^{\circ}$ Convegno Internazionale dei Docenti delle Discipline della Rappresentazione/ Connecting. Drawing for weaving relationships. Proceedings of the 42th International Conference of Representation Disciplines Teachers. Milano: FrancoAngeli, pp. 3183-3202. 


\section{Graphic Design for Universal Information. Pictograms and Communication}

Gabriella Curti

Abstract

Pictograms are images commonly employed in everyday life. They give people lots of information about facilities or directions for getting to and from places. Visitors need to follow signs which are displayed everywhere in places such as airports, railways and docking stations. The Olympic Games are an example of the way in which pictograms have extensively been used to communicate crucial information quickly and effectively to people of all nationalities and understanding. Through my research (that is still in progress) it is possible to make a classification of the examples and suggest following guidelines in design.

Keywords

abstract symbol, information pictograms, sport pictograms, graphic design,

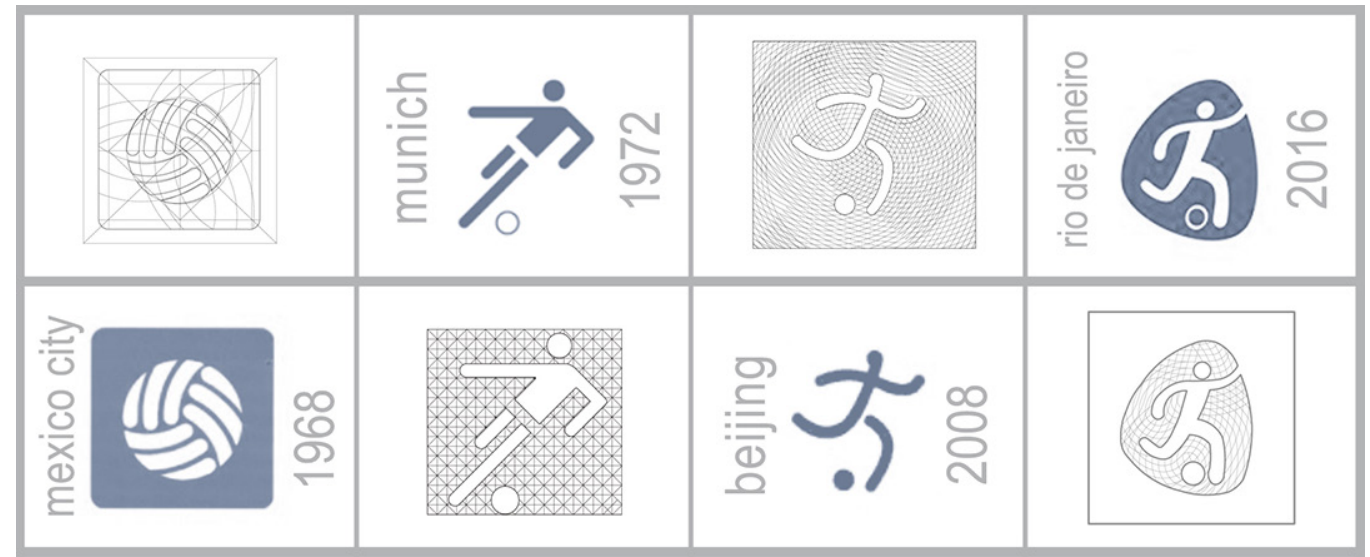




\section{Why pictograms?}

They are elements of the universal language and are really important in their simplicity. Pictograms are elements in which signs and colour are mixed to create a symbolic form to captivate the attention of people and communicate information to them. They are designed and produced after the start of the Isotype [I] method of representation in pictorial form. In the XIX century, Universal Exhibitions were the prime example of the way in which pictograms have extensively been used to communicate to people of all nationalities and understanding. Obviously, pictograms made places more easy to get to and from, and gave people lots of information about venues (exhibition areas) facilities and even basic amenities. As they were understandable, they were utilized to catch a user's attention and to enable them to orientate themselves towards places where they should have gone. In fact, today it is possible to see them everywhere in places such as airports, railways and docking stations. As graphic designers would innovate everything in designing, and would characterize all of their work with their style, it is possible to see many different examples of the same items. My research will be focusing on what pictograms have in common rather than emphasizing their differences. This can be done, in making a list of some pictograms, in order to find also the differences between them. Any different categories (or groups) for shape and usual or unusual colour combination can be classified with the aim of suggesting some guidelines in design.

Fig. I. Black and white pictograms which are usually used everywhere for everyday life to give indications and instructions. Arrows for directions and signs for permitted and signs for permitted (graphic ele actions graphic elaboration by

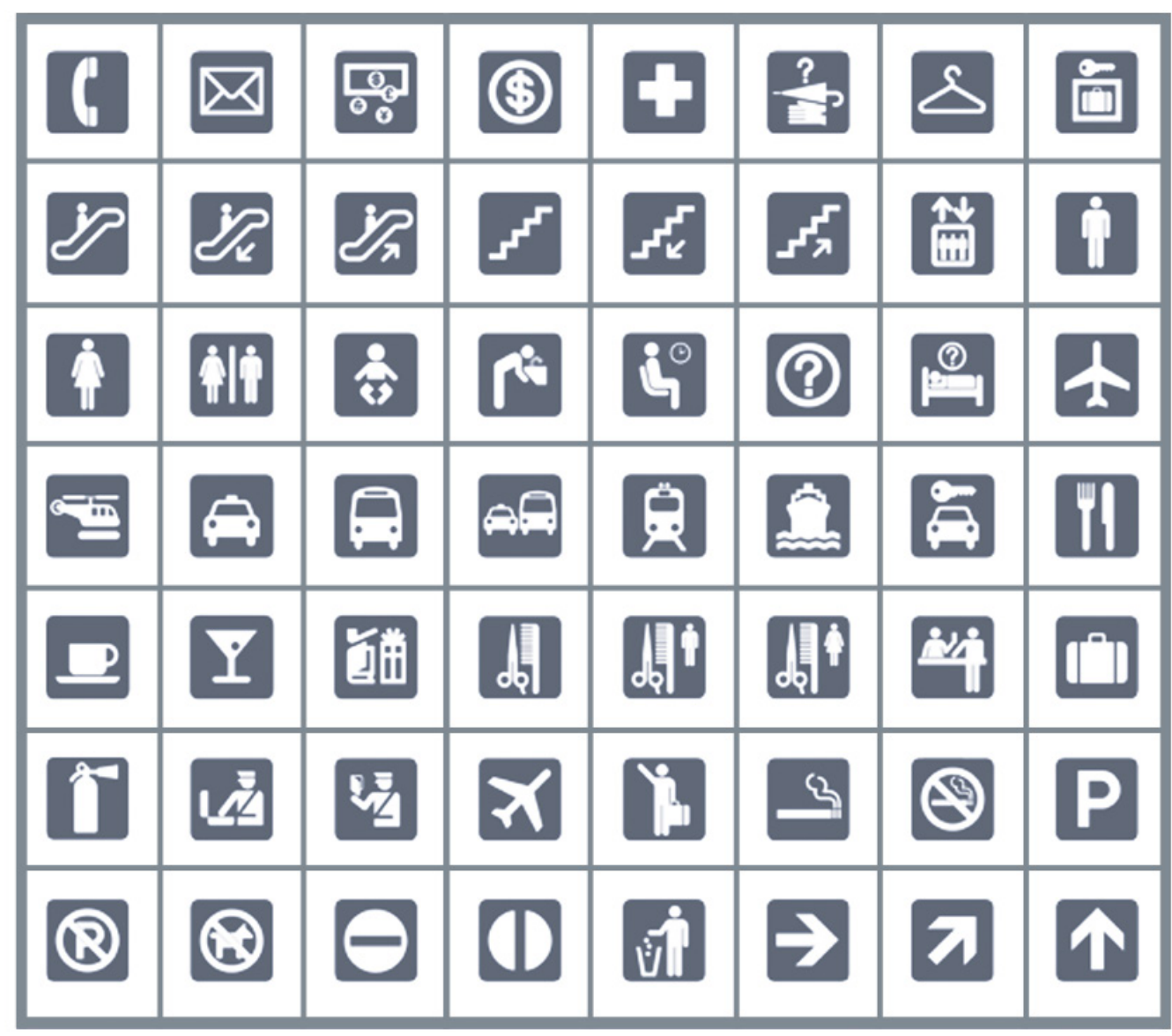




\section{Symbolism and meaning of iconic pictograms}

Pictograms have been utilized throughout ancient civilization such as Sumerian and Assyrian-Babylonian civilization whose cuneiform script (or alphabet) was the earliest known writing system in which symbols were utilized instead of words [2]. It is similar to the shorthand [Heller, Anderson 20 I6, page 102], a quick way of writing by using special signs or abbreviations. It could be also called a visual shorthand.

In addition to this, it can be also compared to other expression forms such as gestural and optical.Today, many people use more gestures than they used to. It may be partly because they come into contact with other nationalities more often than in the past, for example during foreign holidays, and when they also see foreigners watching television. Years ago seeing someone who moved their hands and arms about whilst talking was considered very odd. Nowadays everyone is used to seeing people gesturing and they have started doing it themselves. It is also the same for looking at people in the eyes, to keep eye contact as a way of showing that someone is interested in the other person they are talking to.

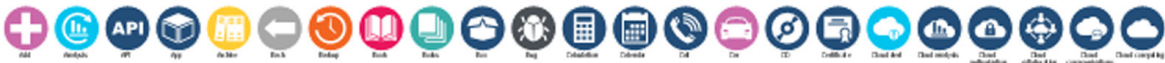

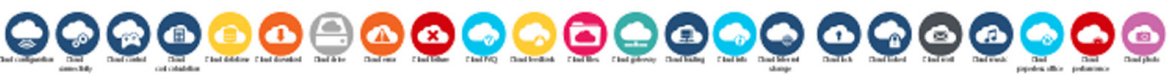

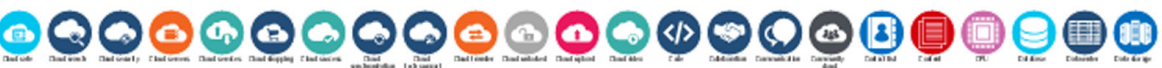

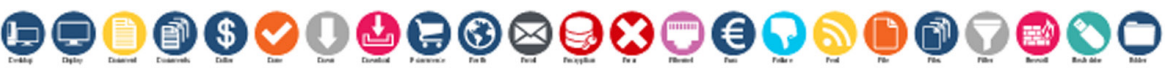

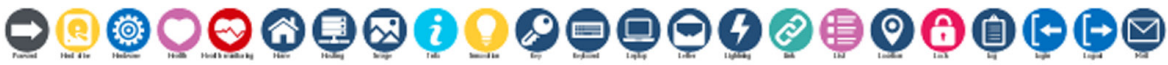

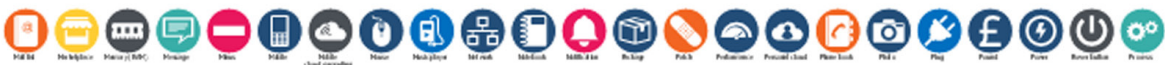

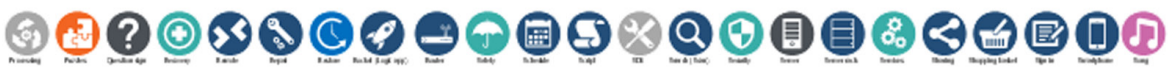

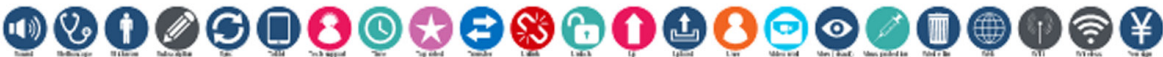

12 Colour Palette
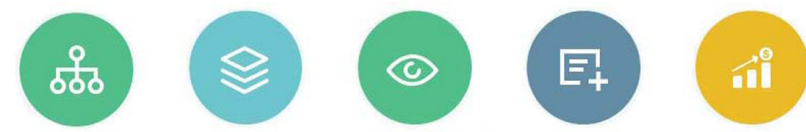

In's
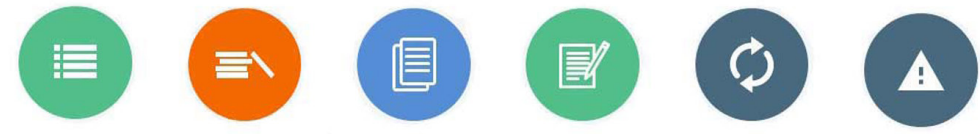

7 Colour Palette
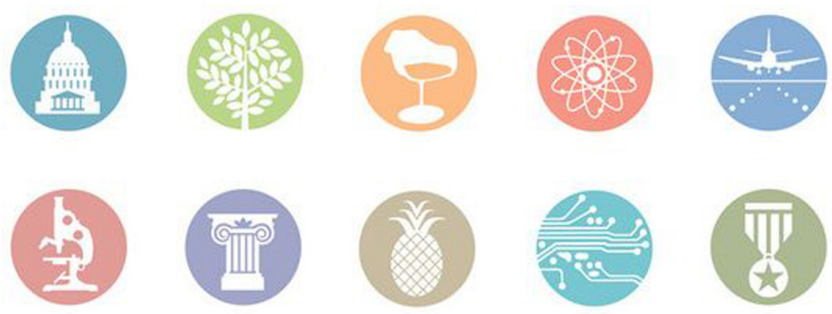

9 Colour Palette 
On the Internet, when writing the emails, punctuation marks are more frequently used for many different meanings. In fact, emoticons (from the two words Emotion and Icon) represent the expression on somebody's face, and show the feelings of the person who is sending the message. For example, the symbol :-) represented a smiling face, but soon after a small digital image, the emoji (from the two Japanese words: E which means 'image' and Moji which means 'character'), which is a tiny yellow smiley face, replaced the emoticon. In this case symbols show physical expressions and it means that pictograms can be visual expressions of everything.

Pictograms function in giving useful information and instructions in various context. For instance, when people have to know directions to reach services and facilities that are available in a public area, or they need to catch public transport, they often follow the arrows positioned everywhere, up and down, on the walls and on the floor, inside and outside. Many pictograms are connected with activities, functions, and their symbolic visual images give instructions to find banks, doctors, emergency services, tourist offices, post offices, police stations, restaurants, cafés, and also car parks, lifts, staircases, escalators, fire extinguishers and so on, as the illustrations show in figures I, 2. All of the symbols carry meaning, like a compass which directs someone towards something. Pictograms are therefore elements of formal language. It is important to make their meaning clear so that people do not misunderstand them, so that they can be used in different international applications.

As shape and colour are the crucial elements in designing pictograms, I will discuss them in the following paragraphs.

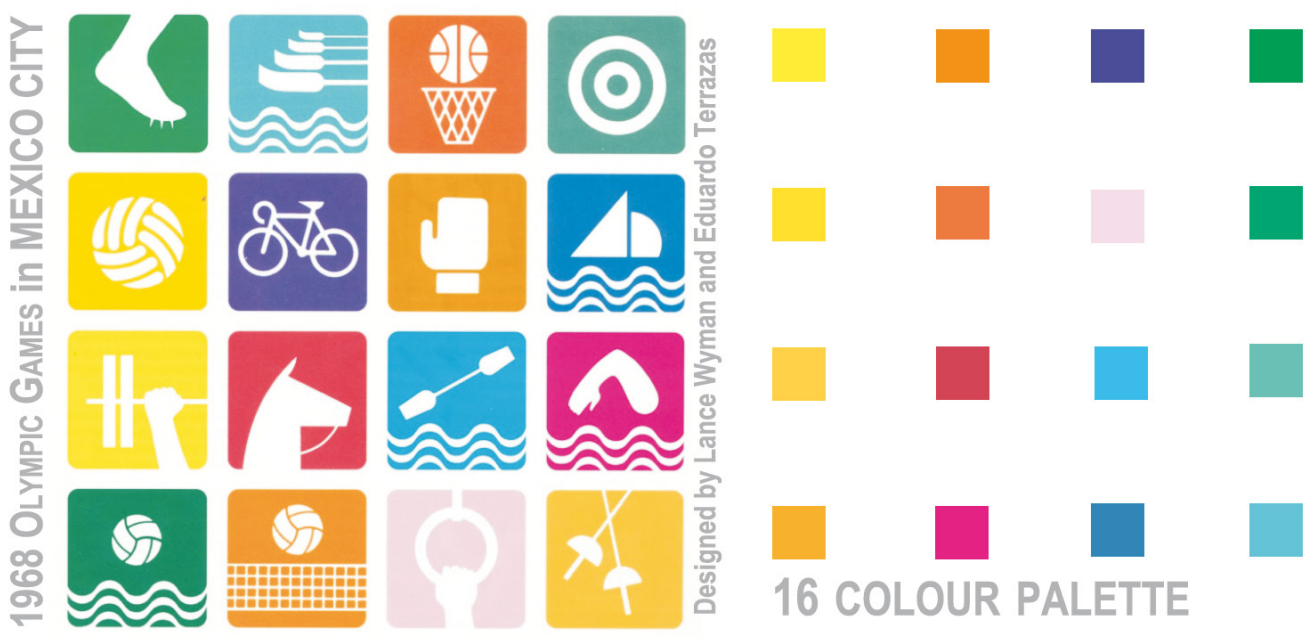

\section{Standard shapes and forms}

It is well known that either the circle or the square play a functional role for pictograms and informative panels. Obviously, to captivate people's attention the circular shape is more frequently used for many pictograms, because circular road signs are the most popular and immediately attract everybody. They generally have a thick or thin contour line which makes the subtle difference between them. However, sometimes white pictograms are on a coloured surface. In fact, a basic squared coloured shape for printed characters can be equally effective to communicate information, and showing which actions are permitted. 
Rectangular shapes are less frequently used, because they don't suit to everything. Their use depends on the symbolic content of the pictogram. Graphic designers rarely choose them, so their use is still experimental. Triangular shapes with rounded corners are highly experimental as well.

People can see all of them, circular, squared, rectangular and triangular pictograms which are displayed on screen and on opaque or transparent surfaces to give specific information. Arrows can be seen everywhere, and point in directions so that users can follow them. Directional arrows, in various size, thick or thin, are displayed at the top and the bottom, even on the floor. In open places, public and private car drivers will seek them for help, when they arrive in an unknown place.

The importance of colour

Colours are instrumental such as other graphic tools, and they represent meanings as well. Generally speaking, the right colour choice can affect the understanding of certain messages, and it is particularly true in this case.
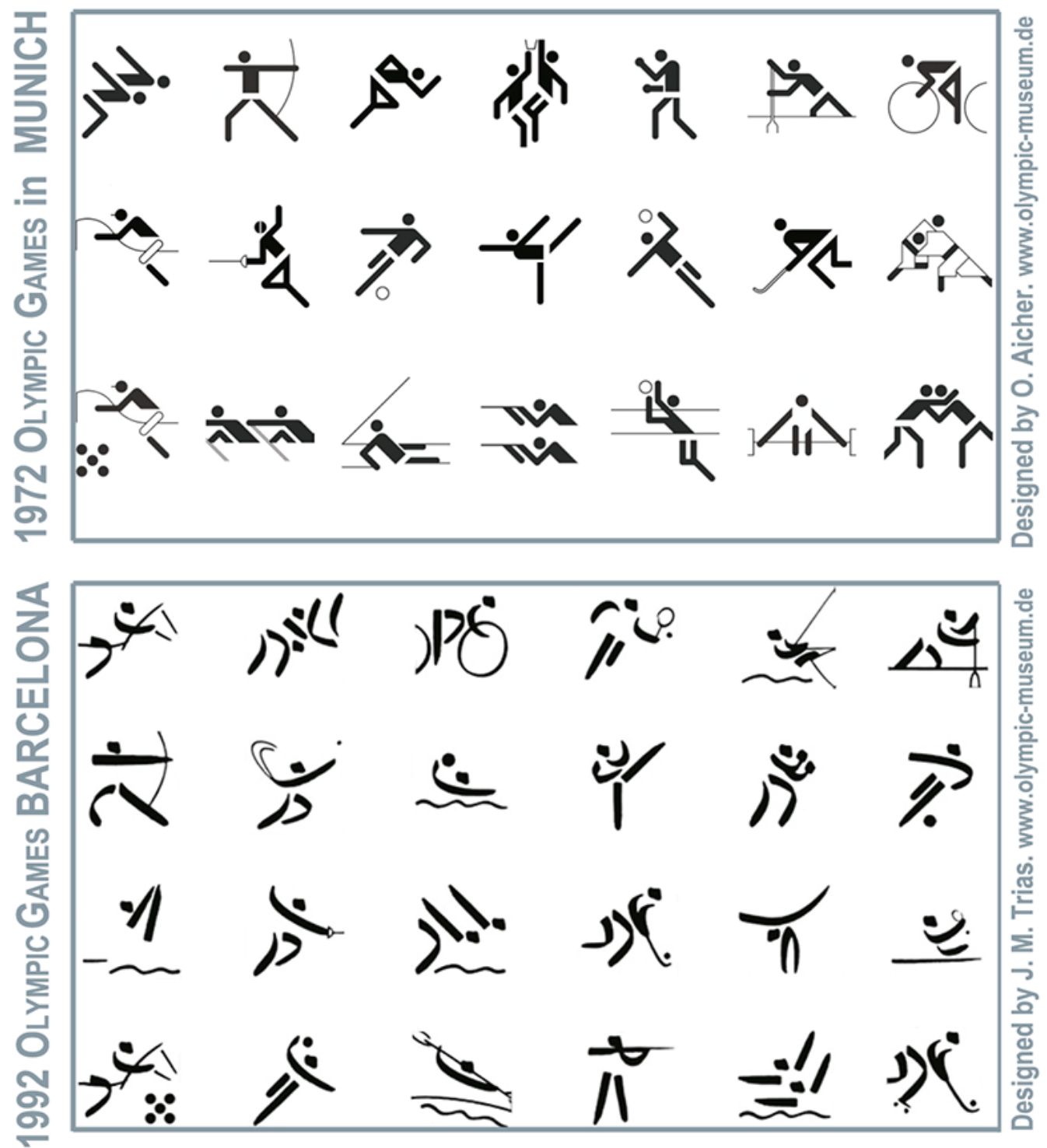
Fig. 5. Left: Pictograms for the 1994 Games in Lillehammer.They were based on the famous 4000-year-old rock carving found in a cave, representing a man epresting a man on skis. Right. Pictograms for Sy 2000 Olympic Games Sydney. Silhouettes are made up of a boomerang, a traditional hunting tool, to pay homage to the Australian Aboriginal culture (graphic elaboration by Gabriella Curti).
For example, circular road signs are the most popular, because speed limit traffic signs usually take the shape of a circle with a white background and thick red border. A red circle with a white rectangle across its face is usually used for one-way traffic in many countries. In European countries a white circle with a thick red border is used on closed roads, and the same colour is used for stop signs, and so on. Obviously, regulatory traffic signs follow international conventions about colours, so that it is possible to see white circles or rectangles with red borders and black pictograms, blue circles or rectangles with white borders and white pictograms. Apart from that, the colour red warns of prohibited actions, whilst the colour blue refers to permitted actions.
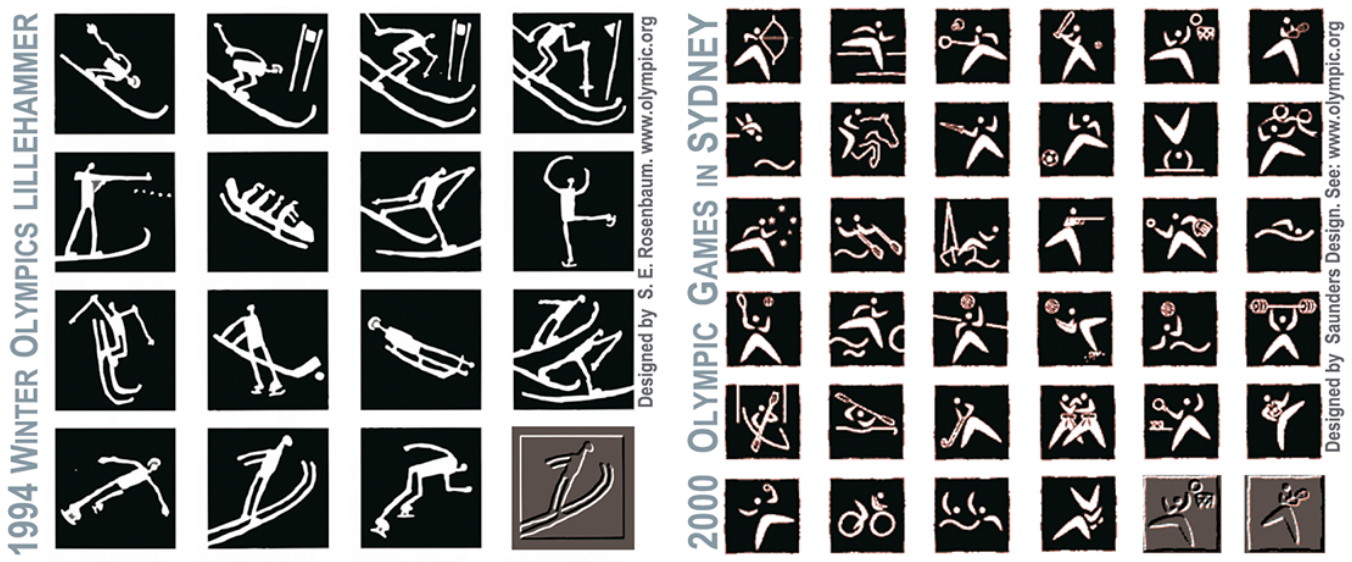

According to experts [3], with six colours (white, yellow, red, green, blue and black) the number of possible combinations is ten. As a consequence, the symbols can be enhanced using vivid colours and vibrant combinations of them. Different colour combinations can communicate different messages. For instance, the colour-code is a system of marking things with different colours so that one can easily identify them. People can follow the colour code carefully on all pictograms, to know the different main functions of the items. However, some researches about International Standards for pictograms, signs and symbols (with a relevance to consumer safety) have shown that the colour coding is not important for sign comprehension when the image is adequate, as long as minimum requirements for legibility are conspicuously satisfied.

\section{Pictograms for the Olympic Games}

The Olympic Games pictograms are qualitatively different. In most cases they are an example of the way in which pictograms have extensively been used to communicate crucial information quickly and effectively to people of all nationalities and understanding. As a result, pictograms are also used as a guide to each sport.

Since 1960s, many pictograms have been commissioned [4], and a lot of effort has been made in the design of sport symbols set in many different ways. Some examples with white pictograms on a coloured surface are in the set for the Olympic Games in Mexico City (1968), in which each sport is represented by depicting body parts and the piece of sports equipment that best represent their essence (fig. 3).

It's well known that the set for the 1972 Olympic Games in Munich is a milestone and it influenced the later edition [5]. As the geometric construction was based on lines and angles of $45^{\circ}$ or $90^{\circ}$ on a checkered square, it shows that pictograms are designed on a system of graphic and geometric rules. An impression of suppleness to the image is given to the Moscow Olympic pictograms (1980), despite some differences in style, they all are similar. In 1992, one difference was the brush painting technique [6] as the illustrations show in figure 4. 
They are symbols which allow people to understand the difference between the various sports, and are purely informative but since the 1980s something has changed, because there began a connection between its historical roots and nature, so that the sports pictograms "became part of the heritage, the Look of the Games and the commercial programme. [...] A new and important change took place for the 1994 Games in Lillehammer where, for the first time, the pictograms told a story. They were based on the famous 4,000-year-old rock carving found in a cave (representing a man on skis). For the first time, a country's heritage was incorporated into the graphic design, something which belonged to Norway and was linked to the winter, or winter sports. It was there that pictograms began to tell a story" [7] In 2000, for the Olympic Games at Sydney the pictograms have a triangular shape similar to a boomerang with dynamic figures inside (fig. 5).

Fig. 6. Pictograms for the 2008 Olympic Games in Beijing. The set name The Beauty of Seal Characters refers to the calligraphic style, so that the pictoto hinake reference chinese culture. The seal-script characters of Ancient Chinese calligraphy serve as basic structure, and give a rounded and smooth aspect to the pictogram (graphic elaboration by

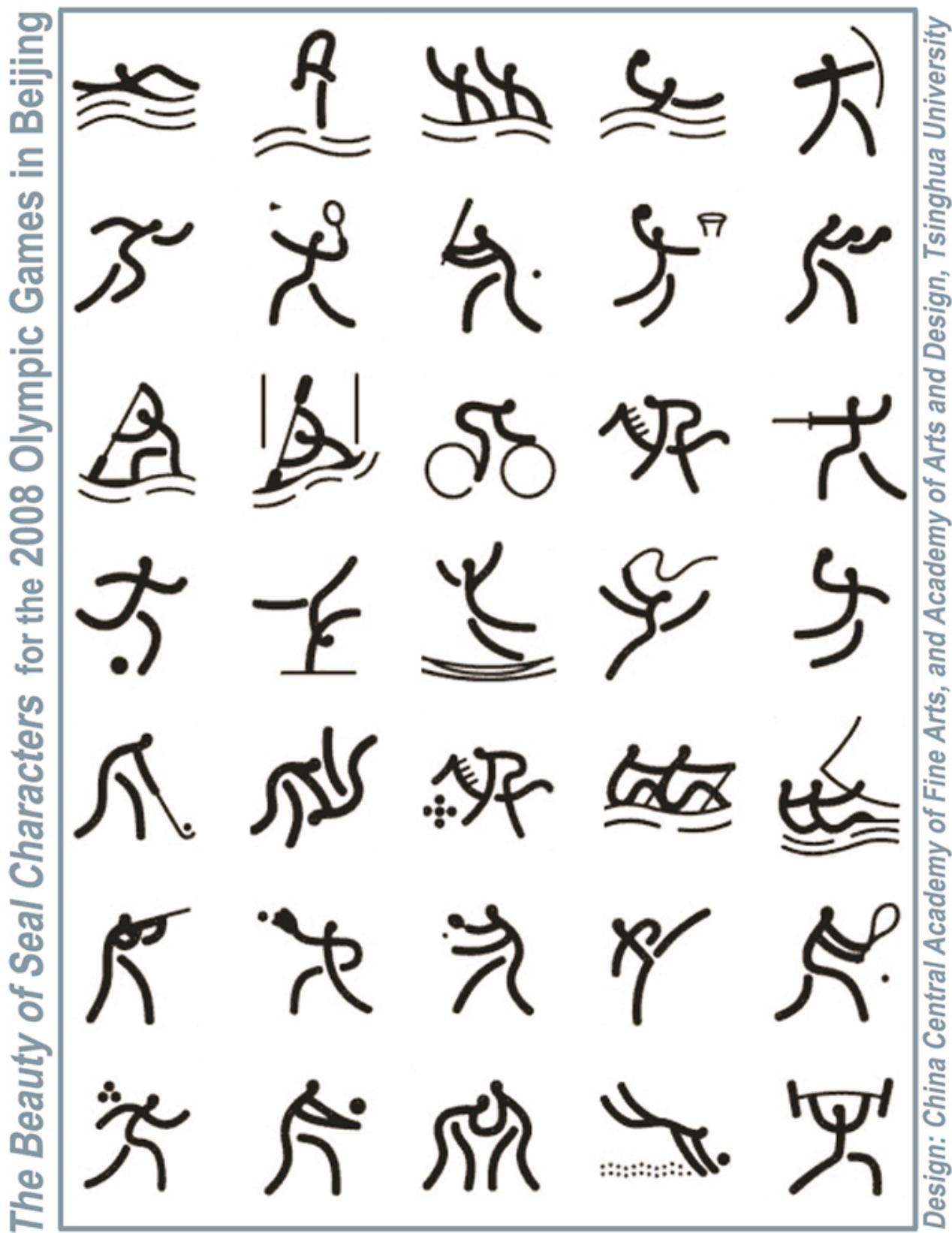


Fig. 7. Pictograms with a white silhouette without contour lines for the London (graphic elaboration by Gabriella Curti).
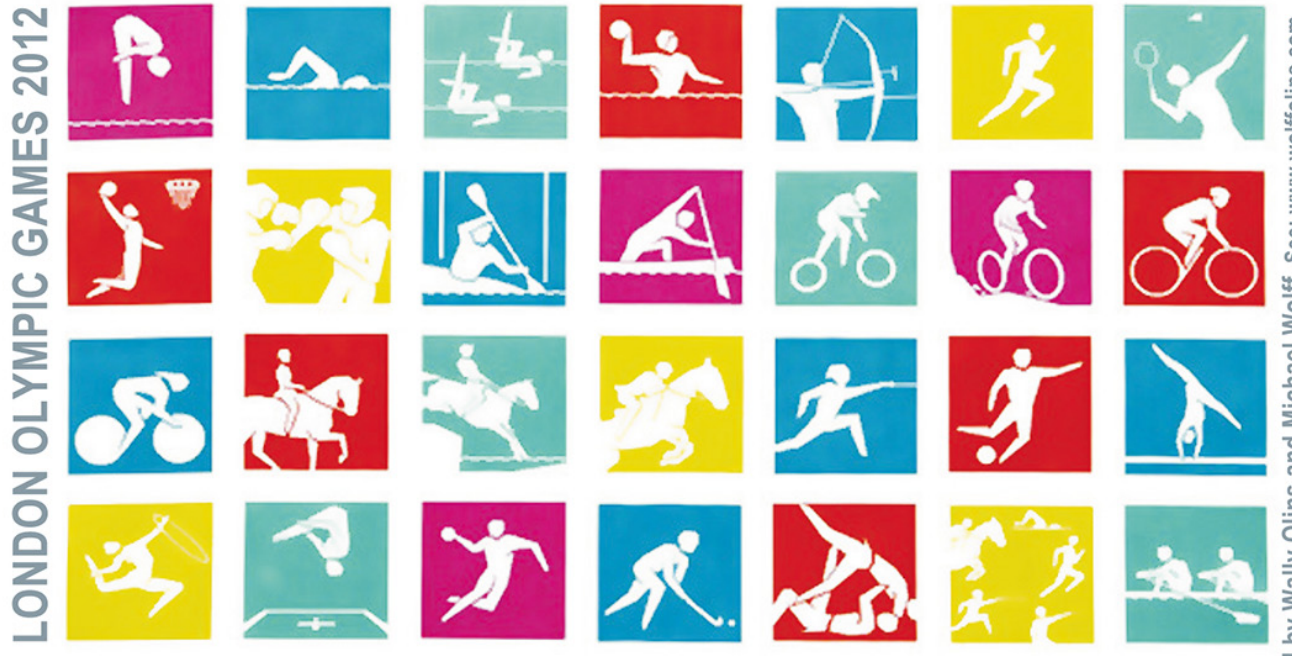

5 COLOUR PALETTE
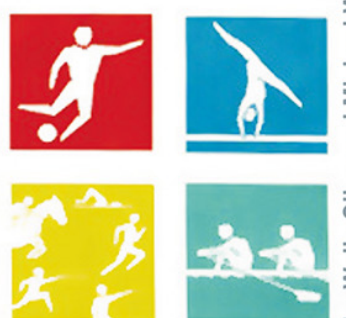

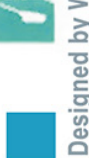

Colours are really important, as well. For the Olympic Games in London (2012) white silhouettes without contour lines are on a coloured surface, so that more importance has been given to the colour contrast (fig. 7) Blue is the coloured surface for the white pictograms for the Olympic Games in Rio de Janeiro (2016). In all of them, each sport was represented by depicting silhouettes and pieces of sports equipment in various ways as the illustrations show in figure 8.

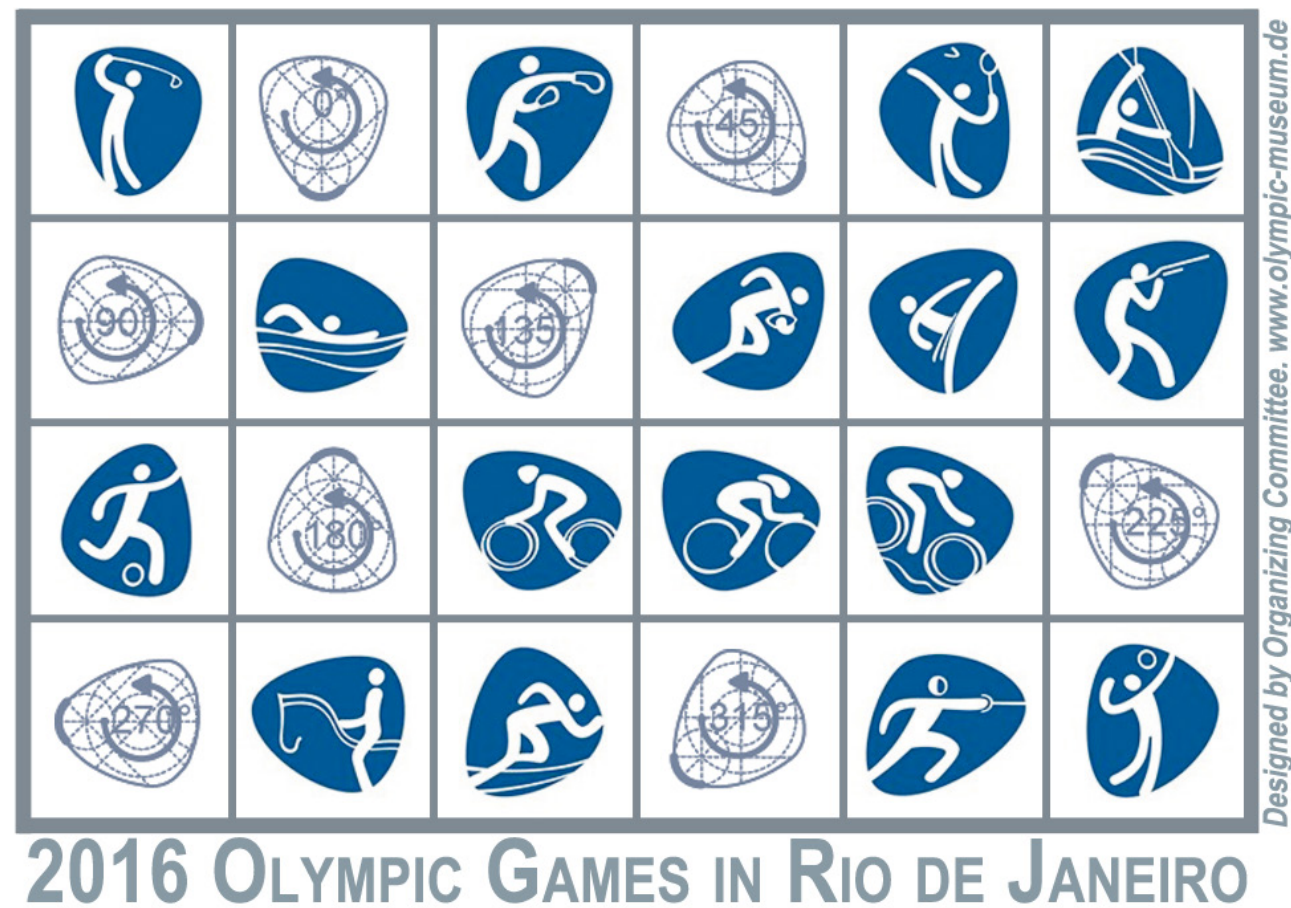




\section{Immediate understanding is the key (in designing)}

As simple shapes and some colours are the main characteristics of pictograms, it probably comes from the theory on abstraction by many artists in the earliest XX century. Wassily Kandinsky had shown that geometrical elements took an increasing importance in both his paintings and writings, so that the simple visual identification of the forms and the main coloured masses were involved in his works. Abstract art uses shapes, colours, forms and gestural marks to achieve its effects, so that forms have been simplified or schematised [Kandinskj 1926].

In standard pictograms, obviously symbols should be both clear in meaning and consistent in their design especially if the purpose of a pictogram is that it can be instantly recognisable and understood by everybody. It could be possible that some graphic designers thought that stringent restrictions had forced them to become more creative even though they have to communicate information. Towards their works it is also possible to learn everything about icon design and cross-cultural communication [8].

As some drawings about sport pictograms show, graphic designers mainly used a system of graphic and geometric rules. By drawing some sport pictograms (particularly football) it seems really important to trace a set of grid lines, or rectilinear and curvilinear traces (fig. 9). In the Seventies, the International Standardization Organisation (ISO) had already defined the pictogram set, and they became global standards. As a result, designers should express their creativity carefully, with attention and respect towards users and customers. They should maintain high qualitative standards too.
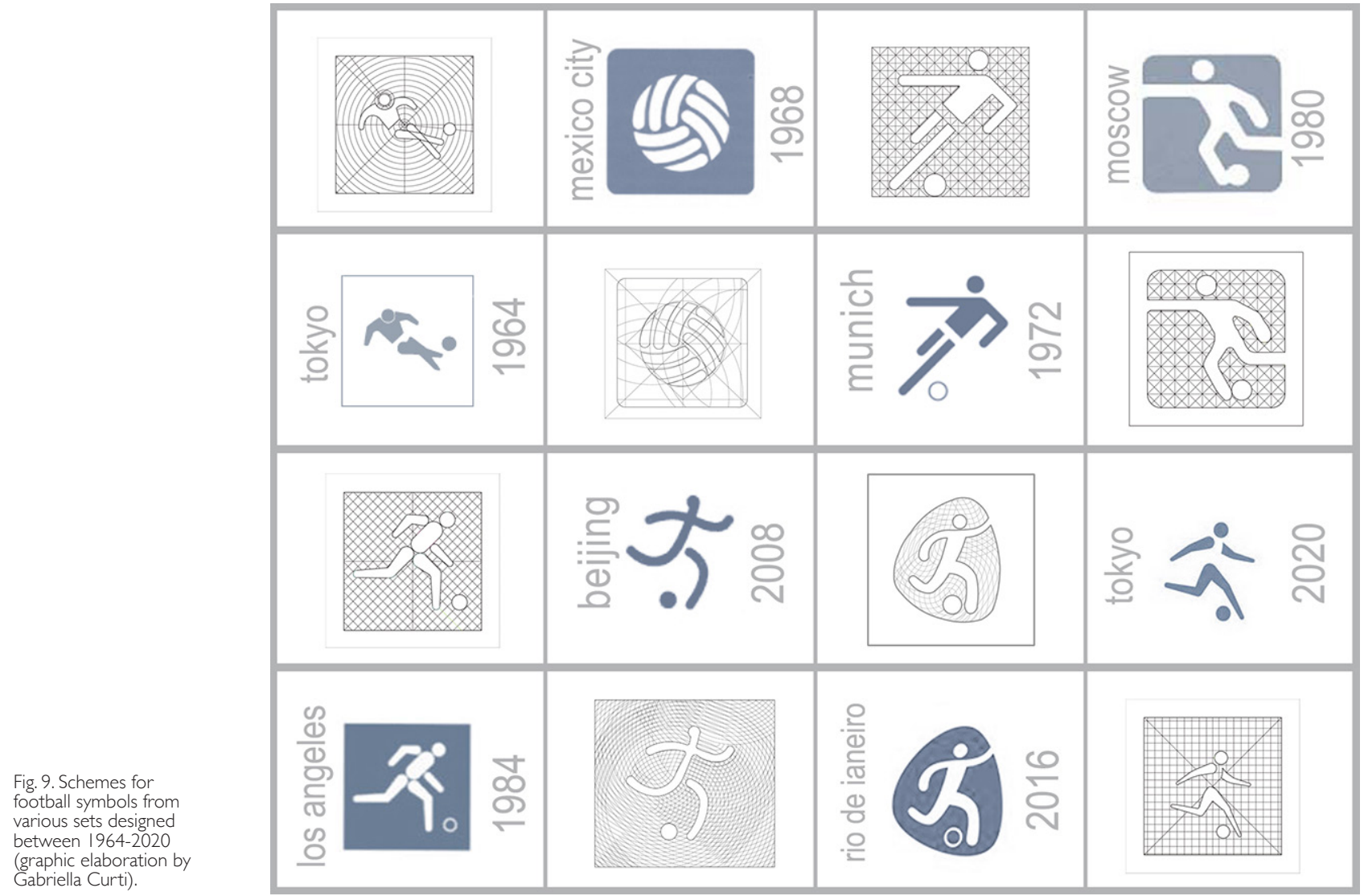

\section{Notes}

[I] Isotype (International System of Typographic Picture Education) consists of standardized and abstracted pictorial symbols to communicate many kinds of complex information about education, security, health and data. They make complex data more accessible, understandable and usable. It was developed between 1925 and 1934. The chief theorist was Otto Neurath, and Gerd Arntz was the graphic author. See: Otto Neurath, 1936. International picture language. London: Kegan Paul, 1936,1 I pages. 
[2] Leveni 2013, pp. 26-30. He wrote: "Pictograms illustrated reality [...] with these symbols people shown atmospheric conditions $[\ldots]$ personal experiences of life. [...] Signs and symbols were used as a spoken language."

[3] Spera 200I, note on page 257.

[4] For example, the 1972 Summer Olympics in Munich by Otl Aicher and the 1988 Olympic Games in Seoul by SLOOC, both only black and white. See also www.olympic.org; by the International Olympic Committee.

[5] Designed by Otl Aicher who also used the same symbols in Montreal 1976 edition.

[6] The 1992 Winter and Summer Games in Barcelona by Josep M. Trias.

[7] M. Osterwalder, Secretary-General of the International Society of Olympic Historians (ISOH), in www.olympic.org. See also: theolympicdesign.com. The Lillehammer 1994 sports pictograms were designed by Sarah E.Rosenbaum whose inspiration came from Norwegian rock paintings.

[8] In 1980, a signage system for the Swiss Federal Railways (SBB) was developed by Josef Müller-Brockman, and it was greatly expanded in 1992. See: Janser and Spalinger 2019.

\section{References}

Aymerich Marta (2008). Simboli, pittogrammi \& silhouette. Modena: Logos (Ed. orig. Symbols, pictograms \& silhouettes. Barcelona: Index Book, 2008).

Gallagher Mark, Savard Laura (Blackcoffee) (2006). 1000 simboli e pittogrammi: comunicazione visiva per tutte le lingue. Modena: Logos (Ed. orig. 1000 Icons, Symbols + Pictograms. Beverly, MA: Rockport Publisher, 2006).

Heller Steven, Anderson Gail (20 I6). Il libro del Graphic Design. Milano:Vallardi (Traduzione a cura di Aster Studio). (Ed. orig. The Graphic Design Idea Book: Inspiration from 50 Masters. London: Laurence King, 20 I6).

Janser Andres, Spalinger Peter (2019). Passenger Information System. Zurich: Integral Lars Müller.

Kandinsky Wassily (1968). Punto, linea, superficie. Milano: Adelphi (Traduzione di Melisenda Calasso). (Ed. orig. Punkt und Linie zu Fläche. Munich: Albert Langen, 1926).

Leveni Paolo (2013). In forma di parola: pittogrammi, ideogrammi, alfabeti, scritture dalla preistoria all'età moderna. Milano: BookTime.

Modley Rudolf, Myers William R. (1976). Handbook of pictorial symbols. 3,250 Examples from International Sources. New York: Dover Publications.

Spera Michele (200 I). La progettazione grafica tra creatività e scienza. Roma: Gangemi editore.

\section{Author}

Gabriella Curti, Università degli Studi Mediterranea di Reggio Calabria, gabriella.curti@unirc.it

To cite this chapter: Curti Gabriella (2020). Sul progetto grafico per l'informazione. Pittogrammi per la comunicazione/Graphic design for universal information. Pictograms and communication. In Arena A., Arena M., Brandolino R.G., Colistra D., Ginex G., Mediati D., Nucifora S., Raffa P. (a cura di). Connettere. Un disegno per annodare e tessere. Atti del $42^{\circ}$ Convegno Internazionale dei Docenti delle Discipline della Rappresentazione/Connecting. Drawing for weaving relationships. Proceedings of the 42th International Conference of Representation Disciplines Teachers. Milano: FrancoAngeli, pp. 3183-3202 